Celal Bayar University Journal of Science

\title{
In vitro Micropropagation of Duckweed (Lemna minor L.) Plant with Temporary Immersion System Bioreactors
}

\author{
Uğur Sidal $^{1 *(D)}$, Zehra Ergönül ${ }^{1}$ (iD \\ ${ }^{1}$ Manisa Celal Bayar University Faculty of Arts and Sciences Department of Biology Manisa, TURKEY \\ * ugur.sidal@bayar.edu.tr \\ *Orcid: 0000-0002-1562-6239
}

Received: 29 December 2020

Accepted: 1 June 2021

DOI: $10.18466 /$ cbayarfbe. 848369

\begin{abstract}
Which is very rich in protein in plant Lemna minor L. abundant in Turkey ecologically plays a very important role in protecting the elimination of water pollution and aquaculture environment balance. In this study, in vitro propagation of this plant with Temporary Immersion System Bioreactor and determination of the effects of used plant growth regulators on the protein content of the plant were aimed. With this objective different variant of media with and without sucrose, varying $\mathrm{pH}$ and concentrations of BAP, kinetin, TDZ in medium were analyzed. Experiments for micropropagation were performed for 8 hours in the dark and 16 hours in white fluorescent light $(150 \mu$ mol photons $\mathrm{m}-2 \mathrm{~s}-1)$ under photoperiod and at $24 \pm 1^{\circ} \mathrm{C}$. The highest plant growth was observed at $\mathrm{pH} 7.23$ in sugar free liquid MS medium containing $0.2 \mathrm{mg} / \mathrm{L}$ BAP. 50.44 plants per explant were recorded in this medium. In addition, the maximum number of plants per explant in liquid MS medium containing $0.05 \mathrm{mg} / \mathrm{L}$ kinetin was calculated as 57,823 and the maximum number of plants per explant in liquid MS medium containing $0.6 \mathrm{mg} / \mathrm{L}$ TDZ was calculated as 50.74. As a result of nitrogen determination studies with Kjeldahl method, the protein value of the plant was determined as $25.5 \%$. As a result of hormone application, it was seen that protein content in plant increased to $29.18 \%$ with $0.5 \mathrm{mg} / \mathrm{L}$ BAP. It was concluded that the aim of the study were fulfilled and positive effects of Temporary Immersion System Bioreactors on plant multiplication were found.
\end{abstract}

Keywords: In vitro, Temporary Immersion System Bioreactors, Lemna minor, Micropropagation

\section{Introduction}

Aquatic plants, the main producers of the aquatic environment, are chlorophyll-containing organisms of various forms, from one cell to multiple cells. These plants, which are the primary producers, carry out photosynthesis using carbon dioxide and light energy present in the water and form plant sources as the first link in the food chain of the aquatic environment [1].Organic degradation in the aquatic ecosystem is extremely important for the biological cycle. The oxygen supply required for aerobic bacteria and fungi responsible for organic degradation is provided by aquatic plants and indirectly, the plants are important in the aquatic environment for the degradation of organic wastes [2].As is known, aquatic plants play a role in the removal of pathogenic bacteria and are used for phytoremediation and bioaccumulation as they are indicator plants with a large growth potential in industrial wastewater [3]. Lemna minor is a very small and simple plant in the Lemnaceae family of Arales, which is free-floating or submerged [4]. This species is a nutritional source of energy, studies on it are gaining momentum in recent years and increasing importance. It is a very rich plant in terms of protein [5]. L. minor is of great ecological importance. In recent years, the use of plants in the elimination of pollution by various factors in natural waters has been increasing. It has a large growth potential in industrial wastewater and is one of the leading plants used for phytoremediation as it is an indicator plant [3].Studies have shown that L. minor is also effective in eliminating the pollution caused by petroleum hydrocarbons. L. minor species synthesize cysteine and other sulfur-containing amino acids by absorbing sulfur from toxic gases such as $\mathrm{SO}_{2}$ and $\mathrm{H}_{2} \mathrm{~S}$. They also have a very high percentage of minerals and essential amino acids such as methionine and lysine [6,7]. Lemna minor is also used in proteomic and genomic research. It has been developed for the production of recombinant therapeutic proteins due to 
its high protein content. Lemna Expresion System (LEX); it allows rapid clonal growth of transgenic plants, release of recombinant proteins, high protein production [8].Thanks to its rapid propagation and tissue culture techniques, its usage areas are gradually increasing and the studies related to the subject gain momentum.

The proliferation and rooting of plants from organized meristems, somatic cells that have not yet matured or completed maturation, either directly (organogenesis or somatic embryogenesis) or indirect (callus, protoplast, etc.) are generally called micro-propagation [9].Micropropagation is considered to be one of the most advantageous methods for propagation in tissue culture techniques if appropriate nutrients, hormone and culture requirements are required by plants. With this technique it is possible to obtain disease-free plants. Variety is increasing due to somaclonal variation and production is carried out in a shorter time and using less rootstock than other techniques [10]. In tissue culture techniques, solid nutrient media are generally used. In these studies, explants placed in solid nutrient medium begin to darken due to the presence of gelling agents that solidify the nutrient medium and are therefore transferred periodically to new media after 4-6 weeks. Contamination of the material is very high during these transfers. Micropropagation studies in solid nutrient environments where gelling agents are used are higher contamination risk and more costly applications compared to tissue culture studies in liquid nutrient media [11]. For this reason, liquid culture media without solidifying agents are particularly preferred for commercial micropropagation. In liquid culture media, the entire surface of the plant explants is in contact they absorb the components in the nutrient media better. The use of bioreactors used in liquid culture media in micropropagation studies is therefore increasing [12].The most common problem in bioreactor systems in which liquid culture media are used is the observation of hyperhydricity due to the fact that the plant material remains in the nutrient medium continuously. Therefore, recently developed temporary immersion system bioreactors are used which enable the plant to move away from the liquid surface at certain intervals. Temporary immersion system bioreactors were first developed by Haris and Mason [13] and the first successful plant regeneration results were obtained from somatic embryos of Solanum tuberosum and Coffea arabica [11].Unlike other bioreactor systems in temporary immersion system bioreactors, a surface has been developed which can provide temporary contact between explant and liquid nutrient media from time to time. With the air flow, the environment goes up in certain time intervals and ensures that the plant receives the necessary nutrients. During the dipping process, air flow and nutrient media penetrate the plant and pass to the tissues without damaging the material. Temporary immersion system bioreactors are used as suitable systems for somatic embryogenesis and organogenesis for this purpose. In this study, in vitro propagation of the plant with temporary immersion system bioreactor is aimed and with the use of bioreactor, it is aimed to keep the ambient conditions at an optimum level and to reproduce the plant in a faster time and healthier than the natural conditions. Also; The aim of this study is to determine the effects of plant growth regulators used for micro-propagation of plant on growth rate and plant protein quality.

\section{Materials and methods \\ 2.1.Plant material}

Duckweed (Lemna minor L.) obtained from Ankara University Faculty of Agriculture Department of Fisheries were used in this study.

\subsection{Growth media and culture conditions in in vitro studies}

Basic nutrient medium containing MS (Murashige and Skoog basal medium) mineral salt and vitamins and $3 \%$ sucrose and solidified with $0.8 \%$ agar (Type A, Sigma-Aldrich Corporation St Lo. Mo) or $0.6-0.65 \%$ agar (Duchefa Netherlands) were used in the experiments. Agar was not added in liquid culture experiments. Double distilled water was used in the preparation of the medium and plant growth regulators of different constructions were added to the nutrient medium when necessary. The $\mathrm{pH}$ of the nutrient medium was adjusted to $5.6-5.8$ by using $1 \mathrm{~N} \mathrm{NaOH}$ or $1 \mathrm{~N} \mathrm{HCl}$, followed by autoclaving at $120^{\circ} \mathrm{C}$ for 20 minutes under a pressure of $118 \mathrm{KPa}$. All cultures were kept under photoperiod for 16 hours under white fluorescent light $\left(150 \mu \mathrm{mol}\right.$ photons $\left.{ }^{\mathrm{m}-2 \mathrm{~s}-1}\right)$ at $24 \pm 1^{\circ} \mathrm{C}[14]$.

\subsection{Plant growth regulators}

Plant growth regulators BAP (Benzylaminopurine), TDZ (Thidiazuron) and kinetin used in the study were obtained from Sigma Aldrich and Duchefa. The stock solutions of the growth regulators were prepared in the desired amount and proportion after thawing with suitable solvents as recommended by the company. Prepared stock solutions were stored at $4^{\circ} \mathrm{C}$ for two months. Kinetin was added to the media after autoclaving[14].

\subsection{Explant surface sterilization}

For surface sterilization, different doses of commercial bleach and $\mathrm{H}_{2} \mathrm{O}_{2}$ were used in duckweed [14].

\subsection{Determination of nitrogen and protein in plant material}

Kjeldahl method was used to determine the protein and nitrogen contents of the plants which were micropropagated and dried [15]. 


\subsection{Statistical evaluation of data}

Regeneration experiments were performed with 3 replications. The data obtained from the studies were analyzed by using SPSS 16 for Windows program on the computer according to factorial experiment pattern. Duncan, LSD or t tests were applied to determine the significance level of the media. Percentage values were subjected to arcsin transformation before statistical analysis [16].

\section{Results}

\subsection{Surface sterilization of the explant}

Surface sterilization of the explants in vitro experiments, Lemna minor plant explants (20 pieces) were first surface sterilized in $20 \%$ commercial bleach, then in $10 \%$ and $20 \% \mathrm{H}_{2} \mathrm{O}_{2}$ for $5,6,7,8,9$ and $10 \mathrm{~min}$. Data obtained as a result of surface sterilization was subjected to variance analysis [17] and the results are given in Table 3.1 .

Table 3.1. Variance analysis of surface sterilization with bleach and $\mathrm{H}_{2} \mathrm{O}_{2}$ at different time and concentrations.

\begin{tabular}{|c|c|c|c|}
\hline $\begin{array}{c}\text { Variance } \\
\text { resources }\end{array}$ & $\begin{array}{c}\text { Degrees } \\
\text { of } \\
\text { freedom }\end{array}$ & $\begin{array}{c}\text { Average } \\
\text { of squares }\end{array}$ & Frequency \\
\hline Time (min) & 5 & 2549,63 & 86,050 \\
\hline $\begin{array}{c}\text { Concentration } \\
(\%)\end{array}$ & 2 & 45029,63 & $1,520 \times 10^{3}$ \\
\hline $\begin{array}{c}\text { Time } \mathrm{x} \\
\text { concentration }\end{array}$ & 10 & 2549,63 & $86,050^{* *}$ \\
\hline Error & 36 & 29,630 & \\
\hline General total & 53 & & \\
\hline
\end{tabular}

$* * \mathrm{p}<0.05$

Table 3.2. Duncan test results of surface sterilization with bleach and $\mathrm{H}_{2} \mathrm{O}_{2}$ at different time and concentrations.

\begin{tabular}{|c|c|c|c|}
\hline \multirow{2}{*}{$\begin{array}{c}\text { Time } \\
(\mathrm{min})\end{array}$} & \multicolumn{3}{|c|}{ Ratio of sterile plants } \\
\cline { 2 - 4 } & $\% 20$ Bleach & $\% 10 \mathrm{H}_{2} \mathrm{O}_{2}$ & $\% 20 \mathrm{H}_{2} \mathrm{O}_{2}$ \\
\hline 5 & 100,00 & 0,00 & $30,00 \mathrm{~d}$ \\
\hline 6 & 100,00 & 0,00 & $50,00 \mathrm{c}$ \\
\hline 7 & 100,00 & 0,00 & $60,00 \mathrm{~b}$ \\
\hline 8 & 100,00 & 0,00 & $100,00 \mathrm{a}$ \\
\hline 9 & 100,00 & 0,00 & $100,00 \mathrm{a}$ \\
\hline 10 & 100,00 & 0,00 & $100,00 \mathrm{a}$ \\
\hline
\end{tabular}

The difference between the means indicated by different letters in the same column is significant at 0.05 level.

As seen in Table 3.1 as a result of the analysis of variance, $5,6,7,8,9$ and 10 minutes with $20 \%$ commercial bleach and $20 \%$ and $10 \% \quad \mathrm{H} 2 \mathrm{O} 2$ concentrations in terms of surface sterilization at 0.05 level is important differences were found. Duncan test [18] results to determine the significance level of these differences are given in Table 3.2. As shown in
Table 3.2 Duncan test results according to $20 \%$ bleach and different time treatment between 0 and $100.00 \%$ sterile plants were obtained. Although the sterilization application was carried out with bleach at different times, $100 \%$ sterile plants were obtained, but whitening was observed due to chlorophyll disintegration. 30 to $100 \%$ sterile plants were obtained by $20 \% \quad \mathrm{H}_{2} \mathrm{O}_{2}$ treatment. However, bleaching and damage of the plants were detected in $20 \% \mathrm{H}_{2} \mathrm{O}_{2}$ treatment for 9 and 10 minutes. No sterile plants were obtained with different time and $10 \% \mathrm{H}_{2} \mathrm{O}_{2}$ treatment. These parameters were used for surface sterilization in the following studies since $100 \%$ sterilization was achieved in plants with 8 minutes and $20 \% \mathrm{H}_{2} \mathrm{O}_{2}$ treatment.

\subsection{The effect of different $\mathrm{pH}$ values on the growth of duckweed in erlenmayer in non-agitated environment}

In vitro study, Lemna minor plant explants were cultured in Erlenmayer for 1 week in non-agitated medium using distilled water at different $\mathrm{pH}$ values. The data obtained after 1 week were subjected to variance analysis and the results are given in Table 3.3. As shown in Table 3.3 as a result of analysis of variance $\mathrm{pH}$ $5,6,7,7.23,8$, and 9 values were found to be significant differences at 0.01 level in reproduction rate, number of plants and total plants per explant. Duncan test results to determine the significance level of these differences are given in Table 3.4. The difference between the means indicated by different letters in the same column is significant at the 0.01 level.Plant growth was observed in all $\mathrm{pH}$ values. Amplification rate ranged from $3.87 \%$ to $280 \%$. The number of plants per explant ranged between 1.47 and 5. The highest increase in the number of plants was obtained at $\mathrm{pH} 5$ with 5 units and the lowest increase was found at $\mathrm{pH} 9$ values with 1.47 units. The total number of plants varied between 7.33 and 25 . The maximum number of plant growths with 5 explants starting at $\mathrm{pH} 7.2325$ units, the least plant formation was recorded as $\mathrm{pH} 97.33$ units. In addition, the number of 19 plants at $\mathrm{pH} 7$ and 25 plants at $\mathrm{pH} 7.23$ were recorded. In addition, 8.33 plants were obtained at $\mathrm{pH} 8$ and 7.33 plants were recorded at $\mathrm{pH} 9$. According to this study, the most ideal $\mathrm{pH}$ range for the plant is 7-7.23, pH range is lower than $\mathrm{pH} 7-7.23$ (65.8) and $\mathrm{pH}$ range is higher than $\mathrm{pH} 7-7.23(\mathrm{pH} 8-9)$ the percentage of plant formation has been observed to fall (Table 3.4).

\subsection{The effect of different $\mathrm{pH}$ values on the growth of duckweed in erlenmayer under agitation}

In vitro experiments, Lemna minor plant explants were cultured in Erlenmayer for 1 week in shaking medium using distilled water at different $\mathrm{pH}$ values. The data obtained after 1 week were subjected to variance analysis and the results are given in Table 3.5. As it is seen in Table 3.5, variance analysis showed that 
significant differences were found in $\mathrm{pH} 5,6,7,7.23,8$ and 9 values in terms of reproduction rate, number of plants per explant, total number of plants, wet weight and dry weight changes. Duncan test results to determine the significance level of these differences are given in Table 3.6. Plant growth was observed in all $\mathrm{pH}$ values. The amplification rate ranged from $-3.33 \%$ to $560 \%$. The number of plants per explant ranged between 0.63 and 6.60 .
The highest increase in number of plants was obtained in $\mathrm{pH} 7$ with 6.60 and the least increase in number of plants was in $\mathrm{pH} 5$ with 0.63 . The total number of plants ranged from 9.67 to 66.00 . The highest plant growth was obtained at $\mathrm{pH} 7$ and the lowest plant growth was at $\mathrm{pH}$ 5. The heaviest plants in weight were $0.7 \mathrm{~g}, \mathrm{pH} 7.23$ and the lightest plants were $0.04 \mathrm{~g}, \mathrm{pH} 5$. Dry weight values in weight of $0.55 \mathrm{~g} \mathrm{pH} 7.23,0.001 \mathrm{~g}$ was observed at $\mathrm{pH} 9$ (Table 3.6).

Table 3.3. Analysis of variance of the effect of different $\mathrm{pH}$ values on the plant growth of duckweed in Erlenmayer in non-agitated medium using distilled water.

\begin{tabular}{|c|c|c|c|c|c|}
\hline \multirow{2}{*}{$\begin{array}{c}\text { Variance } \\
\text { resources }\end{array}$} & \multirow{2}{*}{$\begin{array}{c}\text { Degrees of } \\
\text { freedom }\end{array}$} & \multicolumn{2}{|c|}{ Number of plants per explant (pcs) } & \multicolumn{2}{c|}{ Total number of plants (pcs) } \\
\cline { 3 - 6 } & 5 & Average of squares & $\mathrm{F}$ & Average of squares & $\mathrm{F}$ \\
\hline $\mathrm{pH}$ & 5 & 5,76 & $20,56^{* *}$ & 143,92 & $20,56^{* *}$ \\
\hline Error & 12 & 0,28 & & 7,00 & \\
\hline $\begin{array}{c}\text { General } \\
\text { total }\end{array}$ & 17 & & & & \\
\hline
\end{tabular}

$* * \mathrm{p}<0.01$

Table 3.4. Distilled water using different $\mathrm{pH}$ values in the non-agitated environment in the Erlenmayer effect of duckweed on the plant growth of Duncan test results.

\begin{tabular}{|c|c|c|}
\hline $\mathrm{pH}$ & Number of plants per explant (pcs) & Total number of plants (pcs) \\
\hline 5 & $5,00 \mathrm{a}$ & $10,00 \mathrm{~cd}$ \\
\hline 6 & $3,80 \mathrm{~b}$ & $12,67 \mathrm{c}$ \\
\hline 7 & $2,53 \mathrm{c}$ & $19,00 \mathrm{~b}$ \\
\hline 7,23 & $2,00 \mathrm{~cd}$ & $25,00 \mathrm{a}$ \\
\hline 8 & $1,67 \mathrm{~cd}$ & $8,33 \mathrm{~cd}$ \\
\hline 9 & $1,47 \mathrm{~d}$ & $7,33 \mathrm{~d}$ \\
\hline
\end{tabular}

The difference between the means indicated by different letters in the same column is significant at the 0.01 level.

Table 3.5. Variation analysis of the effect of different $\mathrm{pH}$ values on the plant growth of duckweed in Erlenmayer in shaking environment.

\begin{tabular}{|c|c|c|c|c|c|c|c|c|c|}
\hline \multirow{2}{*}{ V. R } & \multirow{2}{*}{ D. F } & \multicolumn{2}{|c|}{$\begin{array}{c}\text { Number of plants } \\
\text { per explant (pcs) }\end{array}$} & \multicolumn{2}{c|}{$\begin{array}{c}\text { Total number of } \\
\text { plants (pcs) }\end{array}$} & \multicolumn{2}{c|}{ Wet weight (g) } & \multicolumn{2}{c|}{ Dry weight (g) } \\
\cline { 3 - 10 } & A. S & F & A. S & F & A. S & F & A. S & F \\
\hline $\mathrm{pH}$ & 5 & 15,58 & $\begin{array}{c}62,63 \\
* *\end{array}$ & 1470,32 & $\begin{array}{c}73,93 \\
* *\end{array}$ & 0,03 & $\begin{array}{c}65,02 \\
* *\end{array}$ & 0,03 & $222,42 * *$ \\
\hline Error & 12 & 0,25 & & 19,89 & & 0,00 & & 0,00 & \\
\hline $\begin{array}{c}\text { General } \\
\text { total }\end{array}$ & 17 & & & & & & & & \\
\hline
\end{tabular}

$* * p<0.01$

Table 3.6. Different $\mathrm{pH}$ values in the shaking environment of the effect of duckweed plant growth in Erlenmayer Duncan test results.

\begin{tabular}{|c|c|c|c|c|}
\hline $\mathrm{pH}$ & $\begin{array}{c}\text { Number of plants } \\
\text { per explant (pcs) }\end{array}$ & $\begin{array}{c}\text { Total number of } \\
\text { plants (pcs) }\end{array}$ & Wet weight $(\mathrm{g})$ & Dry weight $(\mathrm{g})$ \\
\hline 5 & $0,63 \mathrm{e}$ & $9,67 \mathrm{~d}$ & $0,04 \mathrm{~d}$ & $0,01 \mathrm{c}$ \\
\hline 6 & $1,26 \mathrm{ed}$ & $12,67 \mathrm{~d}$ & $0,41 \mathrm{~d}$ & $0,13 \mathrm{c}$ \\
\hline 7 & $6,60 \mathrm{a}$ & $66,00 \mathrm{a}$ & $0,12 \mathrm{a}$ & $0,07 \mathrm{a}$ \\
\hline 7,23 & $4,70 \mathrm{~b}$ & $47,00 \mathrm{~b}$ & $0,70 \mathrm{~b}$ & $0,55 \mathrm{~b}$ \\
\hline 8 & $1,77 \mathrm{~d}$ & $17,67 \mathrm{~d}$ & $0,48 \mathrm{~cd}$ & $0,006 \mathrm{~d}$ \\
\hline 9 & $2,93 \mathrm{c}$ & $29,33 \mathrm{c}$ & $0,05 \mathrm{c}$ & $0,001 \mathrm{~d}$ \\
\hline
\end{tabular}

The difference between the means indicated by different letters in the same column is significant at the 0.01 level. 
3.4.Setting the amount of liquid MS (Murashige and Spoog basal medium) suitable for reproduction in temporary immersion system (TIS) bioreactors

After determining the appropriate $\mathrm{pH}$ for the plant, the studies were carried out to determine the appropriate MS and sugar concentrations in the liquid culture medium to be used for rapid propagation of the plants in the TIS bioreactor. TIS bioreactors to be used in the study were sterilized twice in each autoclave at $126^{\circ} \mathrm{C}$ separately before being used despite any risk of contamination. Afterwards, 20 explants in TIS bioreactors were cultured in medium containing $1 / 4$ MS, 1/2 MS, MS and $30 \mathrm{~g}$ sucrose for 1 week. Initially, $350 \mathrm{ml}$ of liquid culture medium was used in the bioreactors, but after 2 weeks the plants in the bioreactor became completely white. It was observed that the plants did not get enough nutrients in $350 \mathrm{ml}$ liquid culture and their development was insufficient.

\subsection{Liquid MS medium optimization in TIS bioreactors}

Lemna minor plant explants (40 pcs) were cultured in different MS liquid culture medium $(400 \mathrm{ml})$ for 4 weeks. Then the data obtained were subjected to analysis of variance and the results are given in Table 3.7. As seen in Table 3.7, as a result of the analysis of variance in sugar and sugar-free MS, 1/2 MS and 1/4 MS liquid culture media, plant formation rate, number of plants per explant, total number of plants, $\mathrm{pH}$ change in terms of significant 0.01 level differences were found. Duncan test results to determine the significance level of these differences are given in Table 3.8. The rate of plant formation in the experiment ranged between $75.00 \%$ and $143.33 \%$. The number of plants per explant was observed between 0.51 and 1.90. The maximum number of plant growths was obtained in 1.90, 1/4 MS sugar culture medium and the least plant number was 0.51 in MS $1 / 4$ sugar free culture medium. The highest number of plants (38 pcs) was observed in liquid culture medium with 1/4 MS sugar and the lowest number of plants (15 pcs) was observed in 1/4 MS sugar free liquid culture medium. The effects of cultured explants on the $\mathrm{pH}$ of the environment were obtained at the lowest values of 4.88 and 5.66. The lowest change rate $\mathrm{pH} 4.88$ value $1 / 4 \mathrm{MS}$ sugar culture medium with the highest change rate $\mathrm{pH} 5.66$ value was observed in MS sugar-free environment (Table 3.8).

Table 3.7. Analysis of variance of the effects of plant duckweed on different MS liquid culture media.

\begin{tabular}{|c|c|c|c|c|c|c|c|}
\hline \multirow{2}{*}{ V. R } & \multirow{2}{*}{ D. F } & \multicolumn{2}{|c|}{$\begin{array}{c}\text { Number of plants per } \\
\text { explant (pcs) }\end{array}$} & $\begin{array}{c}\text { Total number of plants } \\
\text { (pcs) }\end{array}$ & \multicolumn{2}{c|}{ pH end state } \\
\cline { 3 - 8 } & A. S & F & A. S & F & A. S & F \\
\hline $\begin{array}{c}\text { Different } \\
\text { MS } \\
\text { medium }\end{array}$ & 5 & 0,68 & $16,0^{* *}$ & 224,72 & $61,28^{* *}$ & 0,248 & $424,66^{* *}$ \\
\hline Error & 12 & 0,043 & & 3,66 & & 0,001 & \\
\hline $\begin{array}{c}\text { General } \\
\text { total }\end{array}$ & 17 & & & & & & \\
\hline
\end{tabular}

$* * \mathrm{p}<0.01$

Table 3.8. Duncan test results of plant formation effects of duckweed of different MS liquid culture media.

\begin{tabular}{|c|c|c|c|}
\hline $\begin{array}{c}\text { Proportions of MS } \\
\text { medium }\end{array}$ & $\begin{array}{c}\text { Number of plants per } \\
\text { explant (pcs) }\end{array}$ & $\begin{array}{c}\text { Total number of plants } \\
(\mathrm{pcs})\end{array}$ & $\mathrm{pH}$ end state \\
\hline 1/4 MS with sugar & $1,90 \mathrm{a}$ & $38,00 \mathrm{a}$ & $4,88 \mathrm{e}$ \\
\hline 1/2 MS with sugar & $1,43 \mathrm{~b}$ & $28,67 \mathrm{~b}$ & $4,90 \mathrm{e}$ \\
\hline MS with sugar & $1,25 \mathrm{~b}$ & $25,00 \mathrm{c}$ & $5,10 \mathrm{c}$ \\
\hline $1 / 4$ MS without sugar & $0,51 \mathrm{~d}$ & $15,00 \mathrm{~d}$ & $5,22 \mathrm{~b}$ \\
\hline $1 / 2$ MS without sugar & $1,18 \mathrm{bc}$ & $23,67 \mathrm{c}$ & $5,04 \mathrm{~d}$ \\
\hline MS without sugar & $0,84 \mathrm{~cd}$ & $15,33 \mathrm{~d}$ & $5,66 \mathrm{a}$ \\
\hline
\end{tabular}

The difference between the means indicated by different letters in the same column is significant at the 0.01 level.

\subsection{Application of TDZ (Thidiazuron) in different concentrations}

In vitro experiment, duckweed plant explants (40) were cultured for 4 weeks in MS liquid culture media (400 $\mathrm{ml}$ ) by adding different concentrations of TDZ hormone. The data obtained after 4 weeks were subjected to variance analysis and the results are given in Table 3.9. As shown in Table 3.9 as a result of variance analysis of liquid MS culture medium in different concentrations of TDZ hormone application plant formation rate, number of plants per explant, total number of plants, wet weight and dry weight were found to be significant at the level of 0.01. Duncan test results to determine the significance level of these differences are given in Table 3.10. In this experiment, plant growth was observed in liquid culture MS medium treated with all TDZ hormones. Plant formation ranged 
between $276 \%$ and $2274 \%$. The number of plants per explant was obtained in liquid MS medium containing up to 50,74 units of $0.6 \mathrm{mg} / \mathrm{L} \mathrm{TDZ}$ and in liquid nutrient medium containing $0.3 \mathrm{mg} / \mathrm{L} \mathrm{TDZ}$ as minimum number of plants (8,99 units). Cultured explants showed that the least wet plants were $0.36 \mathrm{~g}$ in liquid MS medium containing $0.5 \mathrm{mg} / \mathrm{L} \mathrm{TDZ}$ and the heaviest plants were found in liquid MS medium containing $1.80 \mathrm{~g}$ and 0.1 $\mathrm{mg} / \mathrm{L}$ TDZ. These results reflected similarly in dry weight. The minimum dry weight in exsplant $0.03 \mathrm{~g}$ and
$0.3 \mathrm{mg} / \mathrm{L}$ TDZ containing liquid nutrient medium and the maximum dry weight of $0.68 \mathrm{~g} 0.1 \mathrm{mg} / \mathrm{L} \mathrm{TDZ}$ containing liquid medium was determined (Table 3.10). In the experiment, the protein ratios of the plants treated with different concentrations of TDZ were calculated. The highest protein content was $26.96 \%$ in liquid MS medium containing $0.2 \mathrm{mg} / \mathrm{L}$ TDZ. The lowest protein content was recorded in liquid MS medium containing $16.48 \%$ and $0.6 \mathrm{mg} / \mathrm{L} \mathrm{TDZ}$.

Table 3.9. The results of variance analysis of the effects of different concentrations of TDZ hormone application on plant growth of duckweed.

\begin{tabular}{|c|c|c|c|c|c|c|c|}
\hline \multirow[t]{2}{*}{ V. R } & \multirow[t]{2}{*}{ D. F } & \multicolumn{3}{|c|}{$\begin{array}{l}\text { Number of plants per explant } \\
\text { (pcs) }\end{array}$} & \multicolumn{3}{|c|}{ Total number of plants (pcs) } \\
\hline & & A. $S$ & \multicolumn{2}{|c|}{$\mathrm{F}$} & A. $S$ & \multicolumn{2}{|r|}{$\mathrm{F}$} \\
\hline $\begin{array}{c}\text { TDZ } \\
\text { hormone }\end{array}$ & 5 & 164,225 & \multicolumn{2}{|c|}{$31510 * *$} & 262983,033 & \multicolumn{2}{|r|}{$\begin{array}{c}3,6980 \\
* *\end{array}$} \\
\hline Error & 12 & 0,005 & & & \multicolumn{2}{|l|}{7,111} & \\
\hline $\begin{array}{c}\text { General } \\
\text { total }\end{array}$ & 17 & & & & & & \\
\hline \multirow{2}{*}{ V. R } & \multirow{2}{*}{ D. F } & \multicolumn{2}{|c|}{ Wet weight (g) } & \multicolumn{2}{|c|}{ Dry weight (g) } & \multicolumn{2}{|c|}{ Protein content (\%) } \\
\hline & & \begin{tabular}{l|l} 
A. S \\
\end{tabular} & $\mathrm{F}$ & A. S & $\mathrm{F}$ & A. $S$ & $\mathrm{~F}$ \\
\hline $\begin{array}{c}\text { TDZ } \\
\text { hormone }\end{array}$ & 5 & 0,757 & $621,896 * *$ & 0,167 & $\begin{array}{c}755,001 \\
* *\end{array}$ & 82,112 & $157,55 * *$ \\
\hline Error & 12 & 0,001 & & 0,00 & & 0,02 & \\
\hline $\begin{array}{c}\text { General } \\
\text { total }\end{array}$ & 17 & & & & & & \\
\hline
\end{tabular}

${ }^{* *} \mathrm{p}<0.01$

Table 3.10. Duncan test results of the effects of different concentrations of TDZ hormone application on liquid culture MS medium to duckweed plant growth.

\begin{tabular}{|c|c|c|c|c|c|}
\hline TDZ $(\mathrm{mg} / \mathrm{L})$ & $\begin{array}{c}\text { Number of } \\
\text { plants per } \\
\text { explant (pcs) }\end{array}$ & $\begin{array}{c}\text { Total number of } \\
\text { plants }(\mathrm{pcs})\end{array}$ & Wet weight $(\mathrm{g})$ & Dry weight $(\mathrm{g})$ & $\begin{array}{c}\text { Protein content } \\
(\%)\end{array}$ \\
\hline 0,1 & $23,74 \mathrm{a}$ & $949,67 \mathrm{a}$ & $1,80 \mathrm{a}$ & $0,68 \mathrm{a}$ & $26,25 \mathrm{~b}$ \\
\hline 0,2 & $15,59 \mathrm{~b}$ & $624,67 \mathrm{~b}$ & $1,25 \mathrm{~b}$ & $0,51 \mathrm{~b}$ & $26,96 \mathrm{~b}$ \\
\hline 0,3 & $8,99 \mathrm{~d}$ & $359,67 \mathrm{~d}$ & $0,99 \mathrm{c}$ & $0,03 \mathrm{f}$ & $22,35 \mathrm{~cd}$ \\
\hline 0,4 & $9,13 \mathrm{c}$ & $365,33 \mathrm{c}$ & $0,90 \mathrm{~d}$ & $0,36 \mathrm{c}$ & $23,31 \mathrm{c}$ \\
\hline 0,5 & $3,76 \mathrm{f}$ & $150,67 \mathrm{f}$ & $0,36 \mathrm{f}$ & $0,16 \mathrm{e}$ & $27,72 \mathrm{a}$ \\
\hline 0,6 & $50,47 \mathrm{e}$ & $219,00 \mathrm{e}$ & $0,63 \mathrm{e}$ & $0,24 \mathrm{~d}$ & $16,48 \mathrm{e}$ \\
\hline
\end{tabular}

The difference between the means indicated by different letters in the same column is significant at the 0.01 level.

\subsection{Bap (6-Benzylaminopurine) hormone application at different concentrations}

In vitro experiments, duckweed plant explants (40 pcs) were cultured in MS liquid culture media (400 ml) for 4 weeks by adding BAP hormone at different concentrations. The data obtained after 4 weeks were subjected to variance analysis and the results are given in Table 3.11. As seen in Table 3.11 variance analysis results of liquid MS culture medium BAP hormone application in different concentrations of plant formation rate, the number of plants per explant, the total number of plants, wet weight and dry weight were found to be significant difference in the 0.01 level.
Duncan test results to determine the significance level of these differences are given in Table 3.12. In the experiment, plant growth was observed in liquid culture MS media where all BAP hormone applications were performed. Plant formation ranged between 220 and 4944.2\%. The number of plants per explant was determined between 2.78 and 50.44 plants. The maximum number of plants was 50.44 in liquid MS medium containing $0.2 \mathrm{mg} / \mathrm{L}$ BAP and the least number of plants $(2,78 \mathrm{pcs})$ in liquid MS medium containing 0.4 $\mathrm{mg} / \mathrm{L}$ BAP. The total number of plants $(2017,7$ pcs) was obtained in liquid MS medium containing $0.2 \mathrm{mg} / \mathrm{L}$ BAP and at least 111.33 in liquid MS medium containing $0.4 \mathrm{mg} / \mathrm{L}$ BAP. Cultured explants had a 
minimum wet weight of $0.15 \mathrm{~g}$ and were detected in liquid MS medium containing $0.4 \mathrm{mg} / \mathrm{L}$ BAP. The heaviest plants were $3.65 \mathrm{~g}$ and were detected in liquid MS medium containing $0.2 \mathrm{mg} / \mathrm{L}$ BAP. In the dry weight calculation of explants, the lightest plants $(0.15$ g) were obtained in liquid MS medium containing 0.1 $\mathrm{mg} / \mathrm{L} \mathrm{BAP}$ and the heaviest plants $(0.7 \mathrm{~g})$ were obtained in liquid MS medium containing $0.4 \mathrm{mg} / \mathrm{L}$ BAP (Table 3.12). In the experiment, protein ratios of plants with different concentrations of BAP were calculated. The highest protein content was $29.18 \%$ in liquid MS medium containing $0.5 \mathrm{mg} / \mathrm{L} \mathrm{BAP}$. The lowest protein content was recorded in liquid MS medium containing $20.45 \%$ and $0.2 \mathrm{mg} / \mathrm{L} \mathrm{BAP}$.

\subsection{Application of kinetin in different concentrations}

In vitro experiments, plant explants of 40 duckweeds were cultured for 4 weeks in MS liquid culture media $(400 \mathrm{ml})$ by adding different concentrations of kinetin hormone; Data obtained after 4 weeks were subjected to variance analysis and the results are given in Table 3.13.

Table 3.11. The results of variance analysis of the effects of different concentrations of BAP hormone administration on duckweed plant growth.

\begin{tabular}{|c|c|c|c|c|c|c|c|}
\hline \multirow[t]{2}{*}{ V. R } & \multirow{2}{*}{ D. F } & \multicolumn{3}{|c|}{$\begin{array}{l}\text { Number of plants per explant } \\
\text { (pcs) }\end{array}$} & \multicolumn{3}{|c|}{ Total number of plants (pcs) } \\
\hline & & A. S & \multicolumn{2}{|c|}{$\mathrm{F}$} & \multicolumn{2}{|l|}{ A. $S$} & $\mathrm{~F}$ \\
\hline $\begin{array}{c}\text { BAP } \\
\text { hormone }\end{array}$ & 5 & 1072,713 & \multicolumn{2}{|c|}{$103400^{* *}$} & \multicolumn{2}{|c|}{1716315,689} & $104000 * *$ \\
\hline Error & 12 & 0,010 & & & 16,500 & & \\
\hline $\begin{array}{c}\text { General } \\
\text { total }\end{array}$ & 17 & & & & & & \\
\hline \multirow{2}{*}{ V. R } & \multirow{2}{*}{ D. F } & \multicolumn{2}{|c|}{ Wet weight $(\mathrm{g})$} & \multicolumn{2}{|c|}{ Dry weight (g) } & \multicolumn{2}{|c|}{ Protein content $(\%)$} \\
\hline & & A. S & $\mathrm{F}$ & A. S & $\mathrm{F}$ & A. S & $\mathrm{F}$ \\
\hline $\begin{array}{c}\text { BAP } \\
\text { hormone }\end{array}$ & 5 & 6,824 & $\begin{array}{c}20650 \\
* * \\
\end{array}$ & 0,019 & $264,459 * *$ & 436,356 & $51700 * *$ \\
\hline Error & 12 & 0,000 & & 0,000 & & 0,05 & \\
\hline $\begin{array}{c}\text { General } \\
\text { total }\end{array}$ & 17 & & & & & & \\
\hline
\end{tabular}

$* * \mathrm{p}<0.01$

Table 3.12. Duncan test results of the effects of different concentrations of BAP hormone application on liquid culture MS medium to duckweed plant growth.

\begin{tabular}{|c|c|c|c|c|c|}
\hline BAP (mg/L) & $\begin{array}{c}\text { Number of } \\
\text { plants per } \\
\text { explant (pcs) }\end{array}$ & $\begin{array}{c}\text { Total number } \\
\text { of plants (pcs) }\end{array}$ & $\begin{array}{c}\text { Wet weight } \\
(\mathrm{g})\end{array}$ & Dry weight $(\mathrm{g})$ & $\begin{array}{c}\text { Protein } \\
\text { content }(\%)\end{array}$ \\
\hline 0,1 & $3,99 \mathrm{~d}$ & $160,00 \mathrm{~d}$ & $2,89 \mathrm{~b}$ & $0,15 \mathrm{~d}$ & $28.43 \mathrm{a}$ \\
\hline 0,2 & $50,44 \mathrm{a}$ & $2017,7 \mathrm{a}$ & $3,65 \mathrm{a}$ & $0,16 \mathrm{~d}$ & $20.45 \mathrm{~d}$ \\
\hline 0,3 & $3,20 \mathrm{e}$ & $128,33 \mathrm{e}$ & $0,30 \mathrm{e}$ & $0,21 \mathrm{c}$ & $21.00 \mathrm{~d}$ \\
\hline 0,4 & $2,78 \mathrm{f}$ & $111,33 \mathrm{f}$ & $0,15 \mathrm{f}$ & $0,70 \mathrm{e}$ & $27.72 \mathrm{~b}$ \\
\hline 0,5 & $5,4 \mathrm{c}$ & $217,00 \mathrm{c}$ & $0,48 \mathrm{~d}$ & $0,24 \mathrm{~b}$ & $29.18 \mathrm{a}$ \\
\hline 0,6 & $5,62 \mathrm{~b}$ & $225,00 \mathrm{~b}$ & $0,66 \mathrm{c}$ & $0,30 \mathrm{a}$ & $26.18 \mathrm{bc}$ \\
\hline
\end{tabular}

The difference between the means indicated by different letters in the same column is significant at the 0.01 level.

As shown in Table 3.13 variance analysis results of liquid MS culture medium kinetin hormone application in different concentrations of plant formation rate, the number of plants per explant, the total number of plants, wet weight and dry weight were found to be significant differences in the 0.01 level. Duncan test results to determine the significance level of these differences are given in Table 3.14. In the experiment, plant growth was observed in liquid culture MS environments where all kinetin hormone applications were performed. Plant formation ranged between $186.67 \%$ and $5683.8 \%$. The maximum number of plants per explant was 57,823 and was obtained in liquid MS medium containing 0.05 $\mathrm{mg} / \mathrm{L}$ kinetin and in liquid MS medium containing at least $2,860.15 \mathrm{mg} / \mathrm{L}$ kinetin. The total number of plants $(2313,3)$ was observed in MS medium containing 0.05 $\mathrm{mg} / \mathrm{L}$ kinetin and at least 114.67 in liquid MS medium containing $0.15 \mathrm{mg} / \mathrm{L}$ kinetin. The least wet weight of cultured explants was found to be $0.24 \mathrm{~g}$ in liquid MS medium containing $0.15 \mathrm{mg} / \mathrm{L}$ kinetin and the heaviest plants were detected in liquid MS medium containing $4.06 \mathrm{~g} 0.05 \mathrm{mg} / \mathrm{L}$ kinetin. 
Table 3.13. Variance analysis of the effects of different concentrations of kinetin hormone application on duckweed plant growth.

\begin{tabular}{|c|c|c|c|c|c|c|c|}
\hline \multirow[t]{2}{*}{ V. R } & \multirow[t]{2}{*}{ D. F } & \multicolumn{3}{|c|}{$\begin{array}{l}\text { Number of plants per explant } \\
\text { (pcs) }\end{array}$} & \multicolumn{3}{|c|}{ Total number of plants (pcs) } \\
\hline & & A. $\mathrm{S}$ & \multicolumn{2}{|c|}{$\mathrm{F}$} & \multicolumn{2}{|l|}{ A. $\mathrm{S}$} & (Pes) \\
\hline $\begin{array}{l}\text { Kinetin } \\
\text { hormone }\end{array}$ & 5 & 1367,854 & \multicolumn{2}{|c|}{$468300 * *$} & \multicolumn{2}{|l|}{2189274,356} & $158200 * *$ \\
\hline Error & 12 & 0,003 & & & \multicolumn{2}{|l|}{4,778} & \\
\hline $\begin{array}{c}\text { General } \\
\text { total }\end{array}$ & 17 & & & & & & \\
\hline \multirow{2}{*}{ V.R } & \multirow{2}{*}{ D. F } & \multicolumn{2}{|c|}{ Wet weight $(\mathrm{g})$} & \multicolumn{2}{|c|}{ Dry weight $(\mathrm{g})$} & \multicolumn{2}{|c|}{ Protein content $(\%)$} \\
\hline & & \begin{tabular}{l|l} 
A. S & \\
\end{tabular} & $\mathrm{F}$ & A. $\mathrm{S}$ & $\mathrm{F}$ & A. $\mathrm{S}$ & $\mathrm{F}$ \\
\hline $\begin{array}{c}\text { Kinetin } \\
\text { hormone }\end{array}$ & 5 & 6,211 & $44040^{* *}$ & 0,44 & $282,622 * *$ & 683,927 & $234150 * *$ \\
\hline Error & 12 & 0,00 & & 0,00 & & 0,006 & \\
\hline $\begin{array}{c}\text { General } \\
\text { total }\end{array}$ & 17 & & & & & & \\
\hline
\end{tabular}

$* * \mathrm{p}<0.01$

In the calculation of dry weight of explants, the lightest plants were observed in nutrient medium containing $0.02 \mathrm{~g}$ and $0.15 \mathrm{mg} / \mathrm{L}$ kinetin and the heaviest plants were observed in liquid MS medium containing $0.39 \mathrm{~g}$ and $0.1 \mathrm{mg} / \mathrm{L}$ kinetin. In the experiment, protein ratios of kinetin treated plants were calculated. The highest protein content was $26.96 \%$ and was observed in liquid MS medium containing $0.15 \mathrm{mg} / \mathrm{L}$ kinetin. The lowest protein content was recorded in liquid MS medium containing $0.2 \mathrm{mg} / \mathrm{L}$ kinetin at $23.18 \%$.

Table 3.14. Duncan test results of the effects of different concentrations of kinetin hormone application on liquid culture MS medium duckweed plant growth.

\begin{tabular}{|c|c|c|c|c|c|}
\hline $\begin{array}{c}\text { Kinetin } \\
\text { hormon } \\
\mathrm{e} \\
(\mathrm{mg} / \mathrm{L})\end{array}$ & $\begin{array}{c}\text { Numbe } \\
\text { r of } \\
\text { plants } \\
\text { per } \\
\text { explant } \\
\text { (pcs) }\end{array}$ & $\begin{array}{c}\text { Total } \\
\text { numbe } \\
\text { r of } \\
\text { plants } \\
(\mathrm{pcs})\end{array}$ & $\begin{array}{c}\text { Wet } \\
\text { weigh } \\
\mathrm{t}(\mathrm{g})\end{array}$ & $\begin{array}{c}\text { Dry } \\
\text { weigh } \\
\mathrm{t}(\mathrm{g})\end{array}$ & $\begin{array}{c}\text { Protein } \\
\text { content } \\
(\%)\end{array}$ \\
\hline 0,05 & $57,82 \mathrm{a}$ & $\begin{array}{c}2313,3 \\
\mathrm{a}\end{array}$ & $4,06 \mathrm{a}$ & $0,19 \mathrm{~d}$ & $24.68 \mathrm{~b}$ \\
\hline 0,1 & $9,11 \mathrm{~b}$ & $\begin{array}{c}364,67 \\
\mathrm{~b}\end{array}$ & $0,90 \mathrm{~b}$ & $0,39 \mathrm{a}$ & $\begin{array}{c}25.44 \mathrm{a} \\
\mathrm{b}\end{array}$ \\
\hline 0,15 & $2,86 \mathrm{f}$ & $\begin{array}{c}114,67 \\
\mathrm{f}\end{array}$ & $0,24 \mathrm{f}$ & $0,02 \mathrm{e}$ & $26.96 \mathrm{a}$ \\
\hline 0,2 & $6,90 \mathrm{c}$ & $\begin{array}{c}276,33 \\
\mathrm{c}\end{array}$ & $0,70 \mathrm{~d}$ & $0,24 \mathrm{c}$ & $23.18 \mathrm{c}$ \\
\hline 0,5 & $3,56 \mathrm{e}$ & $\begin{array}{c}142,67 \\
\mathrm{e}\end{array}$ & $0,32 \mathrm{e}$ & $0,19 \mathrm{~d}$ & $26.18 \mathrm{a}$ \\
\hline 0,6 & $6,67 \mathrm{~d}$ & $\begin{array}{c}267,00 \\
\mathrm{~d}\end{array}$ & $0,79 \mathrm{c}$ & $0,29 \mathrm{~b}$ & $26.84 \mathrm{a}$ \\
\hline
\end{tabular}

The difference between the means indicated by different letters in the same column is significant at the 0.01 level.

\section{Discussion}

The production of aquarium plants in Turkey is made in limited quantities. Aquatic plants in tissue culture work is done in a limited number of countries including Turkey. In this thesis, Lemna minor, one of the aquatic plants, is aimed to be propagated with temporary immersion system bioreactors. In this direction, the production limits of the plant are increased in a faster time than the natural conditions. Turkey from Lemna minor plant previously made on the very few studies about the availability of temporary system does not have to work with the micropropagation bioreactors. Generally, the studies have been carried out on the elimination of water pollution causing substances such as heavy metal wastes by using Lemna minor plant from water sources $[19,20]$. Surface sterilization is one of the most important steps in tissue culture studies. When working with the green part of the plant, the chemicals to be applied to the explant for surface sterilization are very likely to damage the plant. Therefore, the chemicals to be used must be treated in the least amount and as soon as possible. Although there are many studies in the literature on the sterilization of land plants, there are not many studies on surface sterilization of aquatic plants. In this study, commercial bleach and $\mathrm{H}_{2} \mathrm{O}_{2}$ were used for sterilization and the best results were obtained by sterilizing $20 \% \quad \mathrm{H}_{2} \mathrm{O}_{2}$ for 8 minutes. Cook et al. [21] have used sulfuric acid and ethanol in surface sterilization of Kosteletzkya virginica seeds. Straub et al. [22] used bleach or ethanol for surface sterilization of Phragmites australis seeds. Agrawal and Ram [23] studied in vitro germination and micropropagation of water chestnut (Trapa sp.). After surface sterilization, the embryos were placed in NBS (basic semi-solid medium of Nitsch) to obtain plants. Simon and Helliwel [24] found that when the level of chlorophyll a with pure water is lower than $\mathrm{pH} 8$, chlorophyll a rapidly converts to fiophytine a, but in the case where it is greater than $\mathrm{pH} \mathrm{8,} \mathrm{hydrolysis} \mathrm{is} \mathrm{found} \mathrm{to}$ 
leave the phytol group. Studies were carried out to determine the appropriate $\mathrm{pH}$ range in surface sterilized plants. $\mathrm{pH}$ optimization for the plant took a long time. In order to make the optimization, the plants were placed in the distilled water in different $\mathrm{pH}$ levels and were observed in shaking and non-shaking conditions for 1 week. The material was placed in the shaker in the dark medium at $190 \mathrm{rpm}$ and $28^{\circ} \mathrm{C}$ for shaking media. For the shaking environment, it was kept in the climatic chamber in the flasks for 1 week. As a result, the optimum $\mathrm{pH}$ range for the plant was determined to be 7.23 in shaking environment. In the experiment, it was observed that the number of plants in $\mathrm{pH} 8$ and 9 was less than that of $\mathrm{pH} 7.23$, and at $\mathrm{pH}$ values less than 7.23 , it was observed that the plant could not develop and the growth did not occur. Therefore, it was determined that optimum $\mathrm{pH}$ range had an effect on plant growth. Similarly, Kim and Jang [25] used Drosera peltata micropropagation studies of $\mathrm{pH} 3.7,4.7$, 5.7 and 6.7 values and $3 \%(\mathrm{w} / \mathrm{v})$ sucrose containing $1 / 2$ MS medium used. They determined the optimum value for the micropropagation of the plant as $\mathrm{pH}$ 5.7. Perica and Berljak [26] found that $\mathrm{pH}$ is an effective factor in the micropropagation of Drosera spatulata Labill. Simola [27] found that the most effective value of Drosera rotundifolia L. in micropropagation is $\mathrm{pH} 6.00$. After determining the appropriate $\mathrm{pH}$ for the plant, the studies were carried out to determine the appropriate MS and sugar

concentrations in the liquid culture medium to be used for rapid propagation of the plants in the TIS bioreactor. Plants were cultured in medium containing 1/4 MS, 1/2 MS, MS with $30 \mathrm{~g}$ sucrose and without sucrose in TIS bioreactors. According to the optimization results of the liquid culture medium, the best plant growth percentage $(90 \%)$ and the total number of plant formation (38.00) were determined in the liquid culture medium with sugar 1/4 MS. It was determined that the chemical substances and concentrations of the liquid culture medium to be used were effective in the micropropagation of the plant. Similarly, Houllou-Kido et al. [28] Nopalea cochenilifera heterotrophic and photoototrophic plant micropropagation have made. They added $3 \%(\mathrm{w} / \mathrm{v})$ sucrose, $0.8 \%(\mathrm{w} / \mathrm{v})$ agar, 1.0 $\mathrm{mg} / \mathrm{L}$ BAP and $0.1 \mathrm{mg} / \mathrm{L} \mathrm{NAA}$ to the MS medium to be used for micropropagation. At the end of their experiments, they found that in sucrose-containing media 10 times more micropropagation occurs than in non-sucrose-containing media. After determining the sugar and MS concentrations of the liquid culture medium, the effects of different doses of TDZ, BAP and kinetin on the rapid growth of the plant were determined. In the studies, it was observed that the number of plants per explant $(57,823$ units) and the total number of plants (2313,3 units) were obtained more than the BAP and TDZ applications in the application of kinetin at different rates $(0.05-0.6 \mathrm{mg} / \mathrm{L})$. Although the number of plants and reproduction rate were high, the plants were found to be dull and unhealthy, and the plants were found to have hyperhydricity. In another study, TDZ was applied at different doses (0.1-0.6 $\mathrm{mg} / \mathrm{L}$ ) and the maximum number of plants (949.67 pcs) was recorded in liquid culture medium containing 0.1 $\mathrm{mg} / \mathrm{L}$ TDZ. In the rapid amplification study with the addition of TDZ, although the number of plant propagations and percentage of plants per explant were high, it was observed that plants with lesser doses and smaller leaf sizes were formed than BAP at different doses. Then, BAP hormone was applied to the liquid culture media at different doses $(0.1-0.6 \mathrm{mg} / \mathrm{L})$. The maximum number of plants per explant (50.44 units) and the maximum total number of plants (2017.7 units) were obtained at a BAP concentration of $0.2 \mathrm{mg} / \mathrm{L}$. All plants are green and healthy. In addition, no hyperhydricity was observed in plants. Obviously, different doses of plant growth regulators (BAP, kinetin and TDZ) applied in the scope of the study have been found to have effects on plant micropropagation. Micropropagation experiments without hormone supplementation showed no hyperhydricity, whereas hyperhidricity was observed in different concentrations of TDZ and kinetin in plants. This is due to the presence and concentration of some plant growth regulators. In this study, in order to determine the effects of different cytokinin concentrations on the protein content of the plants, microcoproduced dried plants were determined protein and nitrogen by Kjeldahl method. In literature studies, it was not found that protein and nitrogen were determined in Lemna minor plant by this method. In the determination of protein with the plant samples taken from the medium where plant growth regulators were added in the experiments, the amount of $29.18 \%$ protein in the plants obtained as a result of $0.5 \mathrm{mg} / \mathrm{L}$ BAP application, the amount of protein as $27.72 \%$ as a result of $0.5 \mathrm{mg} / \mathrm{L}$ TDZ application and as a result of the application of $0.15 \mathrm{mg} / \mathrm{L}$ kinetin protein amount was determined as $26.96 \%$. Stewart et al. [29] carrot (Daucus carota L.) in the in vitro study carried out in plants developed in the bioreactor due to lack of oxygen have found a negative effect on root elongation. In order to overcome this problem and maintain the $\mathrm{O}_{2}$ balance in the environment, the explants were cultured in auxophyton containing bioreactors and continuous air intake was provided and positive effects were observed in root elongation. It was recorded that the weight of the plant increased 2.6 times after 20 days. Escalant et al. [30] carried out micropropagation of banana plant with temporary immersion system bioreactors and compared the results obtained with the micropropagation test results of banana plant in solid food medium using agar. In the explants cultured in TIS bioreactor, the number of somatic embryos formed after 2 months was recorded as 1375 and the number of embryos in agar containing solids was 450. As a result, the percentage of plant growth in micropropagation by bioreactor application was 3.05 times higher than the percentage of plant growth in micropropagation in agar medium. 
As a result, the propagation of Lemna minor plant with temporary immersion system bioreactors was carried out successfully and the plant was produced in a shorter time and more number than the natural environment. The negative risks that may occur during the production phase have been completely eliminated under laboratory conditions and production has been carried out in a controlled manner. It was determined that plant growth regulators used during micropropagation did not have a negative effect on plant protein ratio and it was seen that it caused an increase in the protein ratio of the plant. Even though in recent years has accelerated studies on aquatic plants are considered to be especially important open about the work in this field in Turkey. Therefore, especially tissue culture studies with aquatic plants are very important. It is thought that this study carried out with Lemna minor plant will contribute to the rapid and intensive production of aquatic plants and will contribute to future aquatic plant biotechnology studies.

\section{Author's Contributions}

\section{Ethics}

There are no ethical issues after the publication of this manuscript.

\section{References}

1. Bornette $G$ and Puijalon S (2011). Response of aquatic plants to abiotic factors: a review. Aquat. Sci., 73:1-14. doi: 10.1007/s00027010-0162-7

2. Khataee AR, Movafeghi A, Torbati S, Salehi Lisar SY, Zarei M (2012). Phytoremediation potential of duckweed (Lemna minör L.) in degradation of C.I. Acid Blue 92: Artificial neural network modeling. Ecotoxicol. Environ. Saf., 80:291-298

3. Wang WC and Freemark K (1995). The use of plants for environmental monitoring and assessment. Ecotoxicol. Environ. Saf., 30: $289-301$

4. Steven MD, Egbert H van N, Rudi MMR (2005). Growth limitation of Lemna minor due to high plant density. Aquat. Bot., 81: 245-251

5. Rusoff LL, Blakeney Jr. EW, Culley Jr. DD (1980). Duckweeds (Lemnaceae family): a potential source of protein and amino acids. J. Agric. Food Chem., 28(4): 848-850

6. Nayyef MA and Amal AS(2012). Efficiency of duckweed (Lemna minor L.) in phytotreatment of wastewater pollutants from basrah oil refinery. J. of Appl. Phytotech. in Environ. Sanitation, 1 (4): 163-172

7. Uysal Y (2013). Removal of chromium ions from wastewater by duckweed, Lemna minor L. by using a pilot system with continuous flow. J. Hazard. Mater., 263: 486-492

8. Cox KM, Sterling DJ and Regan JT (2006).Glycan optimization of a human monoclonal antibody in the aquatic plant Lemna minor. Nat. Biotechnol., 12: 1591-1597
9. Brown DCW and Thorpe TA (1995). Crop improvement through tissue culture. World Journal of Microbiology and Biotechnology, 11: 409-415

10. Khvatkov P, Chernobrovkina M, Okuneva A, Dolgov S (2019). Creation of culture media for efficient duckweeds micropropagation (Wolffia arrhiza and Lemna minor) using artificial mathematical optimization models. Plant Cell Tiss Org Cult 136: 85-100

11. Etienne H, Berthouly M (2002).Temporary immersion systems in plant micropropagation. Plant Cell Tiss. Org. Cult., 69: 215-231

12. Aitken-Christie J and Davies HE (1988). Development of a semiautomated micropropagation system. Acta Hortic., 230, 81-88 doi: 10.17660/ActaHortic. 1988.230.7

13. Harris RE and Mason EBB (1983). Two machines for in vitro propagation of plants in liquid media. Can. J. Plant Sci., 63(1): 311 316, doi: $10.4141 /$ cjps83-032

14. Yenice $Z$ (2010). Micropropagation of common duckweed (Lemna minor L.) plants using temporary immersion system bioreactors. Master Thesis, Ankara University Biotechnology Institute, Ankara, Turkey

15. Bradstreet RB (1954). Kjeldahl method for organic nitrogen. Anal. Chem., 26(1): 185-187 doi: 10.1021/ac60085a028

16. Snedecor GW and Cochran WG (1967) Statistical Methods. 6th edn. Ames Iowa, Iowa State University Press

17. Scott AJ and Knott M (1974). A cluster analysis method for grouping means in the analysis of variance. Biometrics, 30: 507-512

18. Duncan DB (1955). Multiple range and multiple $F$ tests. Biometrics, 11:1-42

19. Artan RO (2007). Use of duckweed (Lemna sp) for further treatment of heavy metal containing wastewater. Master's thesis. Çukurova University. Institute of Science. Adana, Turkey

20. Memmon A (2008). Elimination of Oil, Hydrocarbon and Pollution by Plant, Algae and Microoganisms. Science and Technology, January number, p 7-8

21. Cook DA, Decker DM and Gallagher JL (1989). Rejeneration of Kosteletzkya virginica (L.) Presl. (Seashore Mallow) from callus cultures. Plant Cell Tiss Org Cult., 17; 111-119

22. Straub PF, Decker DM and Gallagher JL (1988). Tissue culture and long-term regeneration of Phragmites australis (Cav.) Trin. Ex Steud. Plant Cell Tiss Org Cult., 15; 73-78

23. Agrawal A and Mohan Ram HY (1995). In vitro germination and micropropagation of water chestnut (Trapa sp.). Aquatic Botany, 51; $135-146$

24. Simon D and Helliwell S (1998). Extraction and quantification of chlorophyll a from freshwater green algae, Wat. Res., 32:2220-2223

25. Kim KW and Jang GW (2004). Micropropagation of Drosera peltata, a tuberous sundew, by shoot tip culture. Plant Cell Tiss Org Cult., 77: 211-214

26. Perica MC and Berljak J (1996). In vitro growth and regeneration of Drosera spatulata Labill on various media. Hortscience 31: 10331034

27. Simola LK (1978). The effect of several amino acids and some inorganic nitrogen sources on the growth of Drosera rotundifolia in long and short-day condition. Z. Pflanzenphysiol. 90: 61-68

28. Houllou-Kido LM, Costa AF, Lira MA, Farias I, Santos DC, Silva KS, Rivas R, Dias ALF, Alves GD (2009).Viability of Nopalea 
Celal Bayar University Journal of Science

Volume 17, Issue 3, 2021, p 325-335

Doi: $10.18466 /$ cbayarfbe. 848369

cochenilifera (cv. Ipa Sertânia) photoautotrophic micropropagation. VI International Congress on Cactus Pear and Cochineal.

Acta Hort., 811:309-314, doi: 10.17660 / Acta Hortic 2009.811 .42

29. Steward FC, Caplin S \& Millar FK (1952). Investigations on growth and metabolism of plant cells. I. New techniques for the investigation of metabolism, nutrition and growth in undifferentiated cells. Ann. Bot. 16: 57-77

30. Escalant JV, Teisson C, Cote F (1994). Amplified somatic embriyogenesis from male flowers of triploid banana and plantain cultivars (Musa spp). In Vitro Cell. Dev.Biol.30:181-186. 